\title{
Pengembangan Self-Esteem (Harga Diri) Dalam Pembelajaran Pendidikan Agama Islam Di SMKN 1 Ponorogo
}

\author{
Ririn Nuraini, M.Pd \\ Institut Agama Islam Riyadlotul Mujahidin Ngabar Ponorogo \\ ririnnuraini453@gmail.com
}

\section{Abstract}

This study aims: to determine the background of developing self-esteem in Islamic Religious Education (PAI) learning at SMKN 1 Ponorogo; to determine efforts to develop self-esteem in Islamic Religious Education (PAI) learning at SMKN 1 Ponorogo; as well as to determine the supporting and inhibiting factors of developing self-esteem at SMKN 1 Ponorogo. This research design is qualitative. Based on the process of data collection and analysis, this research resulted in: the background for developing self-esteem in Islamic Religious Education (PAI) learning at SMKN 1 Ponorogo is because PAI teachers see that students' self-esteem is still low; efforts to develop self-esteem (self-esteem) are very effective in terms of increasing self-esteem of students. These include: games or group games, motivational video screenings, and inspirational stories; as well as supporting and inhibiting factors for developing self-esteem in Islamic Religious Education Learning (PAI) at SMKN 1 Ponorogo including: student heterogeneity, backgrounds and problems that arise in the family, readiness of students and teachers.

Keywords: Self-Esteem, Islamic Religious Education Learning 


\section{Abstrak}

Penelitian ini memiliki tujuan: untuk mengetahui latar belakang pengembangan self-esteem dalam pembelajaran Pendidikan Agama Islam (PAI) di SMKN 1 Ponorogo; untuk mengetahui upaya pengembangan self-esteem dalam pembelajaran Pendidikan Agama Islam (PAI) di SMKN 1 Ponorogo; serta untuk mengetahui faktor pendukung dan penghambat pengembangan self-esteem di SMKN 1 Ponorogo. Desain penelitian ini adalah kualitatif. Berdasarkan proses pengumpulan dan analisis data, penelitian ini menghasilkan: latar belakang pengembangan self-esteem dalam pembelajaran Pendidikan Agama Islam (PAI) di SMKN 1 Ponorogo adalah karena guru PAI melihat bahwa self-esteem peserta didik masih rendah; upaya pengembangan self-esteem (harga diri) tersebut sangat efektif dalam hal peningkatan self-esteem peserta didik. Di antaranya: game atau permainan kelompok, pemutaran video motivasi, dan kisah inspiratif; serta faktor pendukung dan penghambat pengembangan self-esteem dalam Pembelajaran Pendidikan Agama Islam (PAI) di SMKN 1 Ponorogo di antaranya: heterogenitas peserta didik, latar belakang dan permasalahan yang muncul dalam keluarga, kesiapan peserta didik dan guru.

Keywords: Self-Esteem, Islamic Religious Education Learning

\section{A. Pendahuluan}

Istilah pembelajaran dan pendidikan memang memiliki keterkaitan yang sangat erat, ibarat dua sisi mata uang yang sulit dipisahkan antara dua perbendaharaan kata ini. Dalam kegiatan pembelajaran selalu ada nilai pendidikan yang ingin ditanamkan. Begitu pula dalam dunia pendidikan tentunya terkandung serangkaian kegiatan pembelajaran yang berusaha mengkoneksikan interaksi antara sender 
(guru), message (materi/pesan dan inti pembelajaran), dan received (peserta didik).

Dalam suatu pembelajaran guru tidak hanya sekedar transfer of knowledge, yang terkesan hanya memberikan ilmu pengetahuan saja tanpa memperhatikan diferensiasi individual peserta didik. Agar suatu pembelajaran mampu mencetak output yang tidak hanya cerdas secara intelektual, akan tetapi juga cerdas secara sosial, maka diperlukan tiga aktivitas dalam pendidikan yang harus saling bersinergi yaitu, transfer of values (domain afektif), transfer of knowledge (domain kognitif), dan tranfer of skill (domain psikomotorik). Pendidikan yang tidak mampu memberikan pelayanan seimbang pada tiga aktivitas tersebut akan menghasilkan split of personality.

Dewasa ini, memang sangat diperlukan perhatian secara holistik khususnya dalam bidang pendidikan. Realitas yang sering muncul kepermukaan dan dirasakan telah menjamur di dalam framework masyarakat adalah aksioma mengenai kemampuan diri seseorang dalam hal inteligensinya, di mana inteligensi ini selalu menjadi salah satu hal yang dianggap sebagai satu-satunya indikator yang mampu mendongkrak keberhasilan seseorang. Sebenarnya semua ini tergantung pada mainstream tiap orang dalam memaknai serta worldview mereka terhadap keberhasilan. Jika dikaji lebih mendalam, sisi emosional atau sisi psikologis seorang individu bahkan dapat memegang peran lebih dominan daripada inteligensi.

Sejalan dengan tujuan sekolah untuk mengembangkan kompetensi siswa dari berbagai macam aspek, perlu disadari bahwa terdapat beberapa sisi psikologis yang hendaknya juga ditumbuhkan dalam proses pembelajaran, yaitu pengendalian diri, kebutuhan berprestasi dan penguasaan, serta self-esteem. Karena seperti yang telah diuraikan di atas 
bahwa sisi psikologis juga sangatlah mempengaruhi keberhasilan. Self-esteem sebagai salah satu bagian dari sisi psikologis individu bisa dikatakan memiliki andil besar dalam mempengaruhi kepribadian seseorang. Self-esteem yang tinggi berbanding lurus dengan kesuksesan yang akan dicapainya.

Pembelajaran saat ini haruslah berusaha dan mampu menstimulasi semua bakat serta karakter yang dimiliki peserta didik demi pencapaian keberhasilan pembelajaran yang optimal. Tujuan pembelajaran itu sesungguhnya bukanlah pengalaman (teori saja) akan tetapi pengamalan (aplikasi yang dilandasi teori). Aplikasi atau praktek dapat dikatakan sebagai manifestasi dari teori, di sini guru sebagai master of particular subject memegang tanggung jawab besar demi tercapainya tujuan tersebut. Dalam pendidikan agama Islam selalu mencoba menselaraskan antara keduanya yang disimbolkan dalam pandangan bahwa agama Islam selalu mengharmoniskan antara kehidupan duniawi dan ukhrawi. Dari sini dapat ditarik sebuah kesimpulan bahwa pengalaman agama tidak hanya pemahaman dari segi teori saja, akan tetapi keteguhan untuk istiqomah dalam pengaplikasiannya.

Pendidikan Islam merupakan salah satu bidang studi yang mendapat banyak perhatian dari ilmuan. Hal ini karena disamping perannya yang amat strategis dalam rangka meningkatkan sumber daya manusia, juga karena dalam pendidikan Islam terdapat berbagai masalah yang kompleks. Bagi mereka yang terjun ke dalam dunia pendidikan Islam, mereka harus memiliki wawasan yang cukup tentang pendidikan Islam dan memiliki kemampuan untuk mengembangkan sesuai dengan tuntutan zaman. ${ }^{1}$

${ }^{1}$ Basuki dan M. Miftahul Ulum, Pengantar Ilmu Pendidikan Islam (Ponorogo: STAIN Po. Press, 2007), 1. 
Salah satu faktor penting yang sangat mempengaruhi keberhasilan individu adalah dimilikinya self-esteem yang tinggi dalam dirinya. Harga diri (self-esteem) adalah penilaian individu (self-judgement) terhadap kehormatan dirinya, yang diekspresikan melalui sikap terhadap dirinya. Harga diri mempunyai pengaruh yang kuat terhadap perilaku yang ditampilkannya. Self-esteem juga merupakan pengatur utama perilaku individu atau merupakan pemimpin dari semua dorongan. Kekuatan pribadi, tindakan, dan integritas diri sangat bergantung kepadanya. ${ }^{2}$ Orang tua dan guru memiliki tanggung jawab besar untuk dapat memenuhi kebutuhan harga diri anak peserta didiknya, melalui pemberian kasih sayang yang tulus sehingga anak dapat tumbuh dan berkembang secara wajar dan sehat, yang di dalamnya terkandung perasaan harga diri yang stabil dan mantap. Di sinilah, tampak arti penting peran orang tua dan guru sebagai fasilitator.

Akhmad Sudrajad mengatakan bahwa pentingnya pemenuhan kebutuhan harga diri individu, khususnya pada kalangan remaja, terkait erat dengan dampak negatif jika mereka tidak memiliki harga diri yang mantap. Mereka akan mengalami kesulitan dalam menampilkan perilaku sosialnya, merasa inferior dan canggung. Namun apabila kebutuhan harga diri mereka dapat terpenuhi secara memadai, kemungkinan mereka akan memperoleh sukses dalam menampilkan perilaku sosialnya, tampil dengan kayakinan diri (self-confidence) dan merasa memiliki nilai dalam lingkungan sosialnya.

${ }^{2}$ Mahmud, Psikologi Pendidikan (Bandung: Pustaka Setia, tt), 370.

3 Haryanto, "Pengertian Harga Diri, 2013: (Online) diambil dari http://belajarpsikologi.com/pengertian-harga-diri/, diakses pada 2 November 2013. 
Self-esteem merupakan salah satu faktor keberhasilan individu dalam kehidupannya. Sebagai penilaian terhadap diri sendiri, maka pengembangan self-esteem menjadi bagian penting dalam pendidikan karena diharapkan mampu memproses penemuan konsep diri positif pada jiwa anak.

Dari hasil observasi di SMKN 1 Ponorogo ketika diadakan evaluasi pada mata pelajaran PAI peneliti melihat beberapa fenomena yang seharusnya itu tidaklah terjadi pada waktu pembelajaran, khususnya pada saat ulangan atau evaluasi berlangsung. Ketika evaluasi berlangsung, ada diantara peserta didik yang masih menoleh kanan kiri, ada yang menyontek dan ketika ditanya, mengapa seperti itu, ada yang menjawab belum siap dan ada yang mengatakan tidak bisa mengerjakan sendiri. Selain itu, ketika diadakan diskusi sebagian peserta didik masih enggan mengemukakan pendapatnya di depan teman-teman mereka. Tentunya dengan keadaan seperti ini terlihat bahwa peserta didik masih pasif dalam proses pembelajaran. Fenomena ini tentu menjadi sebuah distorsi dari yang seharusnya. Di mana seharusnya mereka mampu menyadari bahwa diri mereka dapat mengerjakan ulangan dengan kemampuannya sendiri dan juga berani mengemukakan pendapatnya ketika diskusi berlangsung. Dari fenomena di atas bisa dilihat bahwa peserta didik masih memiliki harga diri (self-esteem) yang rendah.

Dari penjajagan awal di SMKN 1 Ponorogo, telah ditemukan beberapa upaya yang dilakukan oleh pihak-pihak terkait dalam meningkatkan pembelajaran Pendidikan Agama Islam guna mengembangkan self-esteem siswa. Guru Pendidikan Agama Islam (PAI) memberikan sejumlah kegiatan diantaranya adalah memberikan video motivasi dan kisah-kisah inspiratif dalam proses pembelajaran yang 
secara disadari ataupun tidak, kegiatan ini akan mampu mendongkrak self-esteem siswa/siswi di SMKN 1 Ponorogo.

\section{B. Latar Belakang Pengembangan Self-Esteem dalam Pembelajaran Pendidikan Agama Islam (PAI) di SMKN 1 Ponorogo}

Dalam pembelajaran Pendidikan Agama Islam (PAI) harus selalu memperhatikan tiga aspek yang ada dalam diri peserta didik, yakni kognitif, afektif, dan psikomotorik. Kecerdasan pikiran bukanlah satu-satunya tolok ukur penunjang keberhasilan seseorang. Dalam hal ini sisi psikologis peserta didik juga tidak kalah penting untuk dikembangkan. Penelitian ini membahas salah satu bagian dari sisi psikologis tersebut, yakni pada masalah self-esteem. Karena self-esteem sangatlah berperan penting terhadap keberhasilan peserta didik, baik dalam hal prestasi, masa depan, maupun kehidupan sosial. Sisi psikologis peserta didik juga sangat berperan dalam menciptakan suasana belajar yang efektif.

Berdasarkan hasil wawancara dan observasi yang telah dilakukan peneliti mengenai latar belakang pengembangan self-esteem dalam pembelajaran Pendidikan Agama Islam (PAI) di SMKN 1 Ponorogo, bahwasannya diperoleh data sebagai berikut:

Sebagaimana data yang diperoleh peneliti, peserta didik masih terlihat pasif dalam pembelajaran, sebagian peserta didik masih menyontek dalam mengerjakan ulangan, peserta didik kurang bersemangat dalam pembelajaran, peserta didik merasa terbebani dengan cara yang dilakukan oleh guru, mereka belum memiliki pandangan yang positif pada diri mereka sendiri dan masih sulit menghargai pendapat orang lain. 
Di mana bentuk kepedulian para guru PAI dalam pembelajaran ini diwujudkan melalui upaya-upaya pengembangan self-esteem peserta didik dengan harapan mereka akan mampu mengembangkan potensi dan menumbuhkan nilai kejujuran dalam diri mereka, peserta didik bisa lebih aktif dan kreatif lagi, berfikiran positif tentang diri mereka, serta mampu menghargai diri sendiri dan orang lain. Hal ini dilakukan tentunya demi keberhasilan para peserta didik. Agar kelak mereka tidak hanya cerdas secara intelektual saja, akan tetapi juga cerdas secara sosial.

Dari deskripsi data yang telah dipaparkan di atas, maka dapat disimpulkan bahwa prinsip pengembangan sungguhsungguh diperhatikan di sana. Pernyataan ini dapat dilihat dari definisi pengembangan pada bab II yakni "proses, cara, perbuatan mengembangkan, bisa juga diartikan pembangunan secara bertahap dan teratur yang menjurus ke sasaran yang dikehendaki". ${ }^{4}$ Artinya pengembangan itu mengisyaratkan adanya usaha atau cara untuk meningkatkan suatu kemampuan agar lebih baik dari sebelumnya. Di mana teori ini sesuai dengan harapan guru PAI dengan adanya upaya pengembangan self-esteem tersebut diharapkan peserta didik akan mampu mengembangkan potensi dan menumbuhkan nilai kejujuran dalam diri mereka, peserta didik bisa lebih aktif dan kreatif lagi, berfikiran positif tentang diri mereka, serta mampu menghargai diri sendiri dan orang lain.

Harapan yang disampaikan oleh guru PAI ini mengisyaratkan bahwa mereka menginginkan terjadi perubahan yang lebih baik pada diri peserta didik, yakni sebelum dan setelah diadakan upaya pengembangan selfesteem tersebut. Diharapkan self-esteem (harga diri) yang

${ }^{4}$ Tim Redaksi Kamus Besar Bahasa Indonesia, Kamus Besar Bahasa Indonesia edisi 3 (Jakarta: Balai Pustaka, 2005), 538. 
positif dalam diri peserta didik dapat berkembang dan bermanfaat bagi mereka.

Latar belakang pengembangan self-esteem di SMKN 1 Ponorogo di atas sesuai dengan teori berikut ini: Individu yang memiliki harga diri positif akan menerima dan menghargai dirinya sendiri sebagaimana adanya serta tidak cepat-cepat menyalahkan dirinya atas kekurangan atau ketidaksempurnaan dirinya. Ia selalu merasa puas dan bangga dengan hasil karyanya sendiri dan selalu percaya diri dalam menghadapi berbagai tantangan. Sebaliknya, individu yang memiliki harga diri negatif merasa dirinya tidak berguna, tidak berharga, dan selalu menyalahkan dirinya atas ketidaksempurnaan dirinya. Ia cenderung tidak percaya diri dalam melakukan setiap tugas dan tidak yakin dengan ide-ide yang dimilikinya. ${ }^{5}$

Latar belakang di atas telah menunjukkan bahwa sebagian peserta didik masih belum percaya pada kemampuan mereka sendiri termasuk menyontek, melihat pekerjaan teman, dan masih pasif dalam proses pembelajaran. Dimana fenomena tersebut mengindikasikan masih rendahnya self-esteem (harga diri) pada diri peserta didik.

Di dalam teori juga dikatakan bahwa self-esteem (harga diri) itu penting dikembangkan karena harga diri dapat membantu orang merasa mampu mengembangkan keterampilannya dan berguna bagi masyarakat. Harga diri yang rendah bisa berkaitan dengan kesehatan, seperti stress, dan bertambahnya ulah "nakal". Selain itu juga penelitian menyatakan bahwa orang perlu akan harga diri yang kuat

${ }^{5}$ Desmita, Psikologi Perkembangan Peserta Didik (Bandung: Remaja Rosdakarya, 2010), 165-166. 
agar merasa yakin berbuat sesuatu dengan menggunakan kemampuan serta bakatnya sebaik-baiknya. ${ }^{6}$

Self-esteem adalah termasuk salah satu dari aspek psikologi. Dengan memperhatikan aspek-aspek psikologi tersebut akan tercipta suatu proses pembelajaran yang efektif dan kondusif. Upaya dalam menciptakan proses pembelajaran efektif, dapat dilakukan dengan cara mewujudkan perilaku mengajar yang efektif pada guru, dan mewujudkan perilaku belajar pada siswa terkait proses pembelajaran.

Dari pemaparan di atas, maka dapat ditarik kesimpulan bahwa antara latar belakang pengembangan self-esteem di SMKN 1 Ponorogo relevan dengan teori yang tercantum pada bab II. Di mana analisis ini didasarkan pada kesesuaian antara realita yang ada di SMKN 1 Ponorogo dan teori yang ada. Secara sederhana dari beberapa teori dan kenyataan yang ada, kesesuaian tersebut dapat dilihat bahwa seharusnya seseorang yang memiliki harga diri positif akan merasa percaya diri dengan kemampuan yang dimilikinya, dan sebaliknya seseorang yang memiliki harga diri negatif menganggap dirinya tidak mampu menyelesaikan tugas sendiri dengan baik.

Untuk mengembangkan harga diri positif serta menciptakan suatu suasana belajar yang efektif, tidaklah mungkin mengabaikan sisi psikologis peserta didik serta komponen pembentuk self-esteem, yaitu penerimaan diri (self-acceptance), menghormati diri sendiri (self-respect), rasa percaya diri (self-confidence), merasa puas terhadap diri

6 Fanny Yovita, Self Esteem, 2008: (Online) diambil dari situs httpswww.google.comsearchq=PENGARUH+SELF+ESTEEM+DALAM+ KEPUASAN+KERJA\&oq=PENGARUH+SELF\&aqs $=$ chrome.0.69i59j69i5 7.12576j0j9\&sourceid=chrome\&es_sm=93\&ie=UTF-8, diakses 26 Maret 2014. 
sendiri (satisfaction as a person). Dari alasan inilah para guru PAI di SMKN 1 Ponorogo memiliki inisiatif untuk melakukan upaya untuk mengembangkan self-esteem peserta didik tersebut.

\section{Upaya Pengembangan Self-Esteem dalam Pembelajaran Pendidikan Agama Islam (PAI) di SMKN 1 Ponorogo}

Sebagaimana data yang diperoleh peneliti di lapangan mengenai upaya pengembangan self-esteem dalam pembelajaran Pendidikan Agama Islam di SMKN 1 Ponorogo, setelah dianalisis terdapat kesesuaian dengan teori yang ada pada bab II. Hal ini dapat dilihat dari penjelasan di bawah ini:

Dalam pembelajaran PAI para guru berusaha menciptakan suatu suasana belajar yang menyenangkan dan kondusif yang diharapkan mampu merangsang peserta didik untuk mengembangkan kompetensi mereka sehingga selfesteem dapat meningkat, diantaranya adalah: game atau permainan kelompok, pemutaran video motivasi, kisah-kisah inspiratif, diskusi, presentasi, drama, debat dalam masalah pendidikan dan kerja kelompok, penilaian lewat teman, melakukan penilaian yang nantinya akan diisi oleh tiap peserta didik yang modelnya seperti angket, dan juga pemberian nasehat, tambahan nilai atau pujian sebagai bentuk penghargaan dengan tujuan agar mereka lebih bersemangat dan percaya diri, membuat papan nama, dan ada juga kegiatan ekstrakurikuler rohis.

Upaya yang dilakukan oleh guru PAI di SMKN 1 Ponorogo guna mengembangkan self-esteem peserta didik di atas adalah wujud nyata dari teori yang ada. Karena kegiatan tersebut berusaha memberikan dukungan emosional dan sosial pada peserta didik dan dapat membantu pencapaian 
prestasi mereka. Sebagaimana teori yang terdapat dalam bab II di bawah ini:

Santrock merumuskan kegiatan dalam membantu meningkatkan harga diri seseorang, ciri-ciri kegiatan tersebut adalah: ${ }^{7}$

1. Kegiatan tersebut dapat untuk mengidentifikasi penyebab rendahnya harga diri.

2. Kegiatan tersebut memberikan dukungan emosional dan sosial pada individu yang bersangkutan.

3. Kegiatan tersebut membantu pencapaian prestasi oleh individu yang bersangkutan.

4. Kegiatan tersebut membantu penyesuaian diri individu yang bersangkutan.

Selain itu juga kegiatan tersebut sesuai dengan teori untuk meningkatkan harga diri seseorang. Maka diperlukan kegiatan-kegiatan yang nantinya mampu menstimulasi rasa harga diri pada peserta didik tersebut agar mampu berkembang. Kegiatan yang bisa dilakukan untuk meningkatkan harga diri siswa di sekolah di antaranya: ${ }^{8}$

1. Memupuk keberanian untuk bertanya

2. Peran guru yang aktif bertanya pada siswa

3. Melatih diskusi dan debat

4. Mengerjakan soal di depan kelas

5. Bersaing dalam mencapai prestasi

Selain itu, prinsip-prinsip pembelajaran yang harus dipegang di antaranya: ${ }^{9}$

${ }^{7}$ Lia Amalia, "Peran Keluarga dalam Pembentukan Harga Diri Remaja, "Cendekia, 1 (Januari-Juni, 2006), 51.

${ }^{8}$ Thursan Hakim, Mengatasi Rasa Tidak Percaya Diri (Jakarta: Puspa Swara, 2002), 136-141.

${ }^{9}$ Ramayulis, Ilmu Pendidikan Islam (Jakarta: Kalam Mulia, 2006), 242-256. 


\section{Aktivitas}

Belajar yang berhasil pasti melalui berbagai macam aktivitas, baik aktivitas fisik maupun psikis. Seluruh peranan dan kemauan dikerahkan dan diarahkan supaya daya itu tetap aktif untuk mendapatkan hasil pembelajaran yang optimal. Sekaligus mengikuti proses pembelajaran secara aktif.

2. Azas Motivasi

Seorang pengajar harus dapat menimbulkan motivasi anak. Motivasi ini sebenrnya banyak dipergunakan dalam berbagai bidang dan situasi, dalam hal ini diarahkan pada bidang pendidikan, khususnya proses pembelajaran. Motivasi ada 2 macam yakni motivasi instrinsik dan motivasi ekstrinsik. Ijazah, nilai yang tinggi, hadiah, ganjaran, penghargaan dan lain-lain termasuk ke dalam motivasi ekstrinsik. Untuk menarik perhatian dan minat peserta didik, guru dapat menggunakan berbagai cara diantaranya: mencari cara belajar yang baik, menggunakan alat peraga yang cukup, intonasi yang tepat dan humor, performance guru yang menarik.

3. Azas Individualitas

Azas individualitas ini hendaknya menjadi perhatian peserta didik. Setiap guru yang menyelenggarakan pembelajaran hendaknya selalu memperhatikan dan memahami serta berupaya menyesuaikan bahan pelajaran dengan keadaan peserta didik.

4. Azas Keperagaan

Peragaan meliputi semua pekerjaan panca indera yang bertujuan untuk mencapai pemahaman sesuatu hal secara lebih tepat dengan menggunaan alat indera. 
5. Azas Ketauladanan

Ketauladanan dalam pendidikan adalah metode yang paling meyakinkan keberhasilannya dalam mempersiapkan dan membentuk moral spiritual dan sosial anak.

6. Azas Pembiasaan

Pembiasaan adalah upaya praktis dalam pembinaan dan pembentukan kepribadian anak. Hasil dari pembiasaan yang dilakukan oleh pendidik adalh terciptanya suatu kebiasaan bagi anak didik.

7. Azas Korelasi

Azas korelasi adalah azas yang menghendaki agar materi pembelajaran antara satu mata pelajaran dengan mata pelajaran lainnya disajikan secara terkait dan integral.

8. Azas Minat dan Perhatian

Setiap individu mempunyai kecenderungan fundamental untuk berhubungan dengan sesuatu yang ada dalam lingkungannya. Apabila sesuatu itu memberikan kesenangan kepada dirinya, kemungkinan ia akan berminat dan perhatian terhadap sesuatu itu.

Dari beberapa contoh bentuk kegiatan tersebut dan juga prinsip-prinsip pembelajaran, maka dapat dibuktikan bahwa upaya pengembangan self-esteem di SMKN 1 Ponorogo sesuai dengan contoh kegiatan di atas. Karena upaya tersebut tetap berusaha memegang prinsip-prinsip pembelajaran yang ada, serta bentuk kegiatan yang dilakukan juga berusaha untuk meningkatkan self-esteem pada diri peserta didik.

Dampak dari adanya pengembangan self-esteem tersebut sangatlah positif. Diantaranya peserta didik menjadi lebih aktif dan kreatif serta lebih antusias karena peserta 
didik merasa lebih diikutsertakan dalam pembelajaran. Mereka merasa lebih dihargai karena keberadaan mereka diperhatikan, dan kita ketahui bahwa sejatinya pembelajaran itu harus mampu berusaha mengkoneksikan antara sender (guru), message (materi/pesan dan inti pembelajaran), dan received (peserta didik). Selain itu dampak positif tersebut dapat dilihat dari sisi kognitif, afektif, dan psikomotorik. Untuk aspek sikap bisa dilihat dari sikap yang mereka tunjukkan sehari-hari. Dengan adanya sikap peserta didik yang lebih menghargai orang lain ini adalah salah satu dampak positif tersebut. Upaya pengembangan self-esteem (harga diri) tersebut sangat efektif dalam hal peningkatan self-esteem peserta didik.

\section{Faktor Pendukung dan Penghambat Pengembangan Self-Esteem dalam Pembelajaran Pendidikan Agama Islam (PAI) di SMKN 1 Ponorogo}

Dalam suatu kegiatan atau proses pembelajaran tentunya tidak akan terlepas dari berbagai kendala yang akan dihadapi. Untuk pengembangan self-esteem dalam pembelajaran PAI di SMKN 1 Ponorogo juga menghadapi beberapa permasalahan. Demi keberhasilan kegiatan pengembangan self-esteem tersebut ada faktor yang mendukung berjalannya upaya tersebut. Selain faktor pendukung terdapat pula faktor penghambat.

Dalam deskripsi data pada bab III telah dipaparkan bahwa: heterogenitas peserta didik, latar belakang dan permasalahan yang muncul dalam keluarga, terlebih dari sisi kurangnya kesiapan peserta didik dalam menerima pelajaran dan guru dalam mempersiapkan materi serta segala sesuatu dalam mengajar, alokasi waktu, media yang cukup representatif dan sangat mendukung dalam proses pembelajaran. Penghargaan dari guru berupa nilai dan pujian 
sangat berperan penting disini juga termasuk kesiapan dalam diri peserta didik dan guru yang baik akan mampu mendukung kegiatan ini.

Dalam teori dikatakan bahwa proses pembentukan harga diri seseorang dimulai sejak kecil. Berbagai pengalaman di rumah, di sekolah, dan saat bersama dengan teman-teman sebaya dapat membantu atau menghambat perkembangan harga diri seseorang. Pembentukan harga diri merupakan sebuah proses fenomenologis, karena ada dalam pandangan dan pikiran seseorang yang bisa saja sesuai dengan kenyataan yang sebenarnya.

Harga diri dipengaruhi oleh beberapa faktor, yaitu faktor pertama adalah sikap perilaku orang tua serta hubungan dalam keluarga; faktor kedua adalah guru, temanteman sebaya, dan sekolah; faktor ketiga adalah jender; faktor keempat adalah persepsi terhadap penampilan fisik; faktor kelima adalah keberartian diri; faktor keenam adalah keberhasilan; faktor ketujuh adalah performansi individu untuk mencapai prestasi yang diharapkan atau rasio keinginan sukses.

Setiap kegiatan tidak selalu berjalan lancar seperti yang diharapkan, akan tetapi pasti ada kendala-kendala yang dihadapi. Kendala-kendala tersebut dapat berasal dari dalam (faktor internal) dan dari luar (eksternal). Faktor-faktor tersebut di antaranya: ${ }^{11}$

1. Faktor Internal

a. Pendekatan metodologi guru monoton, sehingga kurang menarik minat siswa.

10 Lia Amalia,"Peran Keluarga dalam Pembentukan Harga Diri Remaja, "Cendekia, 1 (Januari-Juni, 2006), 45-46.

11 Djamaludin Abdullah Aly, Kapita Selekta Pendidikan Islam (Bandung: Pustaka Setia, 1997), 18. 
b. Kurangnya waktu kesiapan guru dalam pengajaran karena faktor kesibukan yang lain.

c. Guru kurang kompeten untuk menjadi tenaga profesional.

2. Faktor Eksternal

a. Timbulnya sikap orang tua di beberapa lingkungan sekitar sekolah kurang menyadari tentang pendidikan terutama pendidikan agama

b. Situasi lingkungan sekolah dipengaruhi godan-godaan dalam berbagai bentuk.

c. Timbulnya sikap frustasi di kalangan orang tua yang beraggapan bahwa tingginya tingkat pendidikan yang diperoleh tidak akan menjamin untuk mendapatkan pekerjaan yang layak.

Jika dilihat dari teori dan fakta yang ada di SMKN 1 Ponorogo, maka dapat ditarik kesimpulan bahwa ada kesesuaian di antara keduanya. Latar belakang keluarga, peran guru dalam pembelajaran di sekolah, keberartian diri yang didukung oleh pujian dan nilai lebih yang diberikan oleh guru, serta performansi peserta didik dalam mencapai prestasi yang diwujudkan melalui kesiapan mereka dalam kegiatan pembelajaran, alokasi waktu yang tepat, semua ini juga termasuk faktor yang dapat mempengaruhi pengembangan self-esteem di SMKN 1 Ponorogo. Agar upaya pengembangan self-esteem tersebut dapat berjalan lancar, maka faktor pendukung tersebut berfungsi sebagai reinforcement demi tercapainya harapan yang ingin dicapai. Demi kesuksesan pengembangan self-esteem di SMKN 1 Ponorogo tersebut, maka diperlukan kerjasama yang baik dari seluruh warga sekolah. Dengan kerjasama yang baik maka akan lebih mudah mengatasi berbagai permasalahan dan faktor penghambat dalam upaya tersebut. 


\section{E. Kesimpulan}

Latar belakang pengembangan self-esteem dalam pembelajaran Pendidikan Agama Islam (PAI) di SMKN 1 Ponorogo diantaranya adalah: peserta didik masih terlihat pasif dalam pembelajaran, sebagian peserta didik masih menyontek dalam mengerjakan ulangan, peserta didik kurang bersemangat dalam pembelajaran, peserta didik merasa terbebani dengan cara yang dilakukan oleh guru, mereka belum memiliki pandangan yang positif pada diri mereka sendiri dan masih sulit menghargai pendapat orang lain.

Upaya pengembangan self-esteem (harga diri) tersebut sangat efektif dalam hal peningkatan self-esteem peserta didik. Kegiatan tersebut berusaha memberikan dukungan emosional dan sosial pada peserta didik dan dapat membantu pencapaian prestasi mereka. Di antaranya adalah: game atau permainan kelompok, pemutaran video motivasi, kisah-kisah inspiratif, diskusi, presentasi, drama, debat dalam masalah pendidikan dan kerja kelompok, penilaian lewat teman, melakukan penilaian yang nantinya akan diisi oleh tiap peserta didik yang modelnya seperti angket, dan juga pemberian nasehat, tambahan nilai atau pujian sebagai bentuk penghargaan dengan tujuan agar mereka lebih bersemangat dan percaya diri, membuat papan nama, dan ada juga kegiatan ekstrakurikuler Kerohanian Islam (Rohis).

Faktor pendukung dan penghambat pengembangan self-esteem dalam Pembelajaran Pendidikan Agama Islam (PAI) di SMKN 1 Ponorogo di antaranya adalah: heterogenitas peserta didik, latar belakang dan permasalahan yang muncul dalam keluarga, terlebih dari sisi kurangnya kesiapan peserta didik dalam menerima pelajaran dan guru dalam mempersiapkan materi, metode, strategi dalam mengajar, alokasi waktu, media yang cukup representatif 
dan sangat mendukung dalam proses pembelajaran. Penghargaan dari guru berupa nilai dan pujian sangat berperan penting di sini, juga termasuk kesiapan dalam diri peserta didik dan guru yang baik akan mampu mendukung kegiatan ini.

\section{Referensi}

Aly, Djamaludin Abdullah. Kapita Selekta Pendidikan Islam. Bandung: Pustaka Setia, 1997.

Amalia, Lia. "Peran Keluarga dalam Pembentukan Harga Diri Remaja," Cendekia, 1. Januari-Juni, 2006.

Arikunto, Suharsimi. Manajemen Penelitian. Jakarta: Rineka Cipta, 2000.

--------. Prosedur Penelitian Suatu Pendekatan. Jakarta: Rineka Cipta, 1998.

---------. Prosedur Suatu Pendekatan Praktek Edisi Revisi 2. Jakarta: Rineka Cipta, 1993.

Baihaqi, MIF. Psikologi Pertumbuhan. Bandung: Remaja Rosdakarya, 2008.

Basuki dan M. Miftahul Ulum. Pengantar Ilmu Pendidikan Islam. Ponorogo: STAIN Po. Press, 2007.

Damar, Psikologi Self Esteem, 2013: (Online), (http://kesehatan.kompasiana.com/kejiwaan/2013/05/17/p sikologi-self-esteem-560873.html, diakses 02 Januari 2014.

Dept. Agama Proyek Pengadaan Kitab Suci Al-Qur'an. AlQur'an dan Terjemahnya. Jakarta: Bumi Restu, 1978.

Desmita. Psikologi Perkembangan Peserta Didik. Bandung: Remaja Rosdakarya, 2010.

--------. Psikologi Perkembangan. Bandung: Remaja Rosdakarya, $\mathrm{tt}$.

Forum Anak EKIS STAIN Watampone, Definisi Pengembangan, 2014: (Online), 
(https://www.facebook.com/ekis.stain.wtp/posts/6069768 72646720, diakses 24 April 2014.

Hakim, Thursan. Mengatasi Rasa Tidak Percaya Diri. Jakarta:

Puspa Swara, 2002.

Hamalik, Oemar. Kurikulum dan Pembelajaran. Jakarta: Bumi Aksara, 2003.

Haryanto. Pengertian Harga Diri, 2013: (Online), (http://belajarpsikologi.com/pengertian-harga-diri/, diakses 02 November 2013.

Koeswara, E. Teori-Teori Kepribadian. Bandung: Eresco, 1991. Mahmud, Psikologi Pendidikan, Bandung: Pustaka Setia, tt.

Miles, Matthew dan Huberman, A. Michael. Analisis Data Kualitatif. Jakarta: UI Press, 1992.

Moleong, Lexy. Metodologi Penelitian Kualitatif. Bandung: Remaja Rosda Karya, 2000.

Muhaimin. Paradigma Pendidikan Islam Upaya Mengefektifkan Pendidikan Agama Islam di Sekolah. Bandung: Rosdakarya, 2002.

Mukhtar. Desain Pembelajaran PAI. Jakarta: Misaka Galiza, 2003.

Mulyana, Deddy. Metodologi Penelitian Kualitatif: Paradigma Baru Ilmu Komunikasi dan Ilmu Sosial Lainnya. Bandung: Remaja Rosdakarya, 2004.

Mulyasa, E. Kurikulum Tingkat Satuan Pendidikan. Bandung: Remaja Rosdakarya.

Muntholi'ah, Konsep Diri Positif Penunjang Prestasi PAI, Semarang: Gunung jati dan Yayasan al-Qalam, 2002.

Passer, Michael W. dan Ronald E. Smith. Psikology the Science of Mind and Behavior Third Edition. New York: Mc. Graw-Hill Companies, 2007.

Ramayulis. Ilmu Pendidikan Islam. Jakarta: Kalam Mulia, 2006 Sagala, Syaiful. Konsep dan Makna Pembelajaran. Bandung: Alfabeta, 2003. 
Santrock, John W. Life Span Development: Perkembangan Masa Hidup, Edisi 5, Jilid I. terj. Juda Damanik dan Achmad Chusairi. Jakarta: Erlangga, 2002.

Sobur, Alex. Psikologi Umum. Bandung: Pustaka Setia, 2010. Sugiyono. Metode Penelitian Pendidikan: Pendekatan Kuantitatif, Kualitatif, dan R\&D. Bandung: Alfabeta, 2006.

Tafsir, Ahmad. Metodologi Pengajaran Agama Islam. Bandung: Remaja Rosdakarya, 1995.

Thoha, M. Chabib. Metodologi Pengajaran Agama. Yogyakarta: Pustaka Pelajar, 1999.

Tim Penyusun Buku Pedoman Penulisan Skripsi. Buku Pedoman Penulisan Skripsi. Ponorogo: Jurusan Tarbiyah STAIN Ponorogo, 2013.

Tim Redaksi Kamus Besar Bahasa Indonesia. Kamus Besar Bahasa Indonesia Edisi 3. Jakarta: Balai Pustaka, 2005.

Tohirin. Psikologi Pembelajaran Pendidikan Agama Islam. Jakarta: Raja Grafindo Persada, 2006.

Usman, M. Basyiruddin. Metodologi Pembelajaran Agama Islam. Jakarta: Ciputat Pers, 2002.

Utama, Arya. Cara Meningkatkan Harga Diri, 2010: (Online), (http://ilmu psikologi.wordpress.com/2010/01/30/carameningkatkan-harga-diri/, diakses 29 April 2014.

Utari, Rahmania Upaya Sekolah Dalam Pembentukan Self Esteem Siswa melalui Pembelajaran, 2013: (Online) upaya_sekolah_dalam_pembentukan_self esteem_siswa.pdf, diakses 16 Desember 2013.

Yovita, Fanny. Self Esteem, 2008: (Online), (httpswww.google. comsearchq=PENGARUH+SELF+ES TEEM+DALAM+KEPUASAN+KERJA\&oq=PENGAR $\mathrm{UH}+\mathrm{SELF} \&$ aqs $=$ chrome.0.69i59j69i57.12576j0j9\&sourc eid $=$ chrome\&es_sm $=93 \& i e=U T F-8$, diakses 26 Maret 2014. 